\title{
Synthesis, Characterization and Antitumor Activity of Some New Oganotellurium Compounds Containing Azomethine Group, Part One \\ Rafid H. Al-Asadi ${ }^{1}$, Tarik A. Fahad ${ }^{1}$, Bahjat A. Saeed ${ }^{1}$ and Wasfi A. Al-Masoudi ${ }^{2 *}$ \\ ${ }^{1}$ Dept. of Chemistry, College of Education, University of Basrah-Iraq \\ ${ }^{2}$ Dept. of Physiology and Chemistry, College of Veterinary, University of Basrah-Iraq \\ *Author for corresponding. E-mail address: almasoudi59@yahoo.com
}

\begin{abstract}
New tellurated schiff bases were synthesized by the reaction of the corresponding mercurated Schiff bases compounds A1-A3 with tellurium tetrabromide in 1:1 mole ratio and that gave organyltellurium tribromides A4-A6. On the other hand, when mercurated schiff bases and tellurium tetrabromide brought together in 2:1 mole ratio gave diorganyltellurium dibromides compounds A10-A12 followed by reduction with hydrazine hydrate gave new diorganyl tellurides A13-A15. Reduction of compounds A4-A6 by hydrazine hydrate gave new ditellurides A7-A9. All compounds were characterized by elemental analysis, IR, ${ }^{1} \mathrm{H},{ }^{13} \mathrm{C}$ NMR, HSQC-NMR and mass spectra. Invitro anti-tumor bioactivity of some compounds were tested.
\end{abstract}

Keywords: Schiff-base; 3,4-dihydroxy benzaldehyde; Tellurium tetrabromide; HSQC- NMR; Antitumor.

\section{Council for Innovative Research}

Journal: Journal of Advances in Chemistry

Peer Review Research Publishing System

Vol. 8, No. 1

editor@cirworld.com

www.cirworld.com, member.cirworld.com 


\section{INTRODUCTION}

There is an increasing in the synthesis of aromatic organic tellurium compounds containing electron donor nitrogen atom at position ortho to the tellurium atom [1,2] . Thus azo [3], Schiff bases [4,5], N,N-dimethylbenzyl amine [6] and parasubsttituted anilines [2] can be ortho tellurated by various methods. McWhinnie and co-workers [7] prepared bis ( $O$ aminophenyl)ditelluride by the reaction of (2-phenylazophenyl) tellurium trichloride with sodium tetrahydroborate. ALRubaie and co-workers [8] have reported several organotellurium compounds containing amino group in ortho position to tellurium atom, such as $\mathrm{ArTeBr}_{3}, \mathrm{Ar}_{2} \mathrm{Te}_{2}$ and $\mathrm{Ar}_{2} \mathrm{Te}$, by the reaction of corresponding 2-amino aryl mercury chloride with tellurium tetrabromide in glacial acetic acid. These new compounds were used as precursor for the prepartion of new polymers containing tellurium via solution polycondensation techniques [9].

Phenols reacted with tellurium tetrachloride under relatively mild conditions in chloroform or carbon tetrachloride solution to give insoluble aryltellurium trichlorides, even when a twofold quantity of phenols was used $[10,11]$.

Sadekov et al [12] made considerable contributions to the chemistry of tellurated azomethines and several tellurated Schiff bases were prepared and characterized. The ability of $\beta$-bromotellurenylvinyl aldehydes and monohalotellurobenzaldehydes [13] to form schiff base enable this methodology to prepare a wide range of organotellurium compounds containing $-\mathrm{CH}=\mathrm{N}$ groups [14].

The aim of the present work was to synthesize some new diaryltellurium compounds containing azomethine group, and study of their biological activity as antitumor agents.

\section{EXPERIMENTAL}

\subsection{Physical measurements}

The IR spectra were recorded in the range $4000-200 \mathrm{~cm}^{-1}$ on a Pye-Unicam SP3-300 spectrometer using $\mathrm{KBr}$ discs. ${ }^{1} \mathrm{H}$ ,${ }^{13} \mathrm{C}$ and HSQC-NMR spectra were measured on a Brucker at 600, 400 and $250 \mathrm{MHz}$, with TMS as internal reference. Microanalysis for carbon, hydrogen and nitrogen were carried out by a Perkin-Elmer 240B Elemental Analyzer. Mass spectra of compounds were recorded at the analytical laboratory of Tarbiat Modares, University Tehran, Iran using Agilent Technologies-5975C spectrometer at an ionizing potential of $70 \mathrm{eV}$. Melting points of all solid compounds were determined by using a thermo.Scintific (9100), Electro thermal Engineering LTD, and uncorrected.

\subsection{Synthesis}

\section{Arylmercuric chloride containing amino group.}

The compounds (2-amino-5-sulfophenyl)mercury(II)chloride , (2-amino-5- (aminooxysulfonyl) phenyl) mercury(II)chloride , (2-amino-5- carboxyphenyl) mercury(II) chloride, (5-acetyl-2-aminophenyl)mercury(II) chloride , (2-aminonaphthalen-1yl)mercury(II) chloride, (4-hydroxyphenyl)mercury(II) chloride were prepared according to previously published procedure [15].

\section{Synthesis of Arylmercuric chloride containing azomethine group}

A mixture of $8.00 \mathrm{mmol}$ of (2-amino-5-(aminooxysulfonyl)phenyl)mercury (II) chloride (3.25g) or (2-amino-5carboxyphenyl)mercury(II) chloride (2.97g) or (5-acetyl-2-aminophenyl)mercury(II) chloride (2.95g) in $50 \mathrm{ml}$ of ethanol and 3,4-dihydroxybenzaldehyde $(8.00 \mathrm{mmole}, 1.104 \mathrm{~g})$ with $4-5$ drops of sulfuric acid were refluxed with stirring for $2 \mathrm{~h}$. After cooling, the precipitate was collected by filtration and washed several times with ethanol. The solid product was twice recrystallized from a mixture of ethanol and benzene (3:2) to give a yellowish solid of $\mathbf{A 1}$-A3 compounds.

\section{Aryltellurium tribromide (A4-A6)}

The compounds were synthesized according to the literature [16] with some modifications:

A mixture of tellurium tetrabromide $(4.00 \mathrm{mmol}, 1.78 \mathrm{~g})$ and arylmercuric chlorides $\mathbf{A 1}(2.01 \mathrm{~g})$ or $\mathbf{A 2}(1.96 \mathrm{~g})$ or $\mathbf{A} 3(1.95 \mathrm{~g})$ $(4.00 \mathrm{mmol})$ each case in $50 \mathrm{ml}$ of dry chloroform was refluxed with stirring for $4 \mathrm{~h}$ under argon atmosphere. The resulting solution was cooled and filtered. Recrystallization of the product from a mixture of diethyl ether and hexane (7:3) gave a redish-brown solid.

\section{Diaryl ditullrides $\left(\mathrm{Ar}_{2} \mathrm{Te}_{2}\right)$ (A7-A9)}

Aryltellurium tribromide $\mathbf{A 4}(1.97 \mathrm{~g})$ or $\mathbf{A 5}(1.87 \mathrm{~g})$ or $\mathbf{A 6}(1.86 \mathrm{~g})$ (3.00 mmol) was refluxed in ethanol (25 ml). An ethanolic solution of hydrazine hydrate was added drop wise to the refluxing solution until the evaluation of nitrogen was ceased. The resulting solution was cooled to room temperature and filtered. Recrystallization of the product by a hot ethanol gave a dark redish-brown solid of compounds A7-A9. Yields, color and melting points for these compounds are given in Table 1.

\section{Diaryltellurium Dibromides $\left(\mathrm{Ar}_{2} \mathrm{TeBr}_{2}\right)$ (A10-A12)}

A mixture of tellurium tetrabromide $(2.00 \mathrm{mmol}, 0.89 \mathrm{~g})$ and arylmercuric chloride $\mathbf{A 1}(2.01 \mathrm{~g})$ or $\mathbf{A 2}(1.96 \mathrm{~g})$ or $\mathbf{A} 3(1.95 \mathrm{~g})$ $(4.00 \mathrm{mmol})$ in $35 \mathrm{ml}$ of dry chloroform was refluxed with stirring for $4 \mathrm{~h}$ under argon gas atmosphere. The resulting solution was cooled and filtered. Recrystallization of the product from a mixture of ethanol and chloroform (4:1) gave a brown to yellowish brown solid. Yields, colors and melting points for compounds A10-A12 are given in Table1. 


\section{Diaryl tellurides $\left(\mathrm{Ar}_{2} \mathrm{Te}\right)$ (A13-A15)}

Diaryltellurium dibromides $\mathbf{A} 10$ (1.97 g) or $\mathbf{A} 11(1.87 \mathrm{~g})$ or $\mathbf{A 1 2}(1.86 \mathrm{~g}))(2.00 \mathrm{mmol})$ was dissolved in $25 \mathrm{ml}$ of ethanol and refluxed. A solution of hydrazine hydrate in ethanol was added drop wisely to the refluxed solution until nitrogen evolution was ceased. The resulting solution was cooled to room temperature and filtered. The crude product was twice recrystallized from a mixture of ethanol and dichloromethane to obtain a yellow or yellowish orange solid. Yields, colors and melting points for compounds A13-A15 are given in Table 1.

\section{RESULTS and DISCUSSION}

Isolated yields, melting points, colors and carbon, hydrogen, and nitrogen analytical data for all new and organotellurium compounds are given in Table 1. The present work describes the synthesis of new tellurated Schiff bases by reaction of corresponding mercurated Schiff bases (A1-A3), which in turn prepared from the reaction of aryl mercury chloride with 3,4-dihydroxy benzaldehyde, with tellurium tetrabromide in 1:1 ratio to produce the required tellurium containing materials $\left(\mathrm{ArTeBr}_{3}\right)$, that's compounds (A4-A6), (Scheme 1). When tellurated Schiff bases and tellurium tetrabromide brought together in 2:1 ratio gave the symmetrical diaryltelluride dibromides compounds (A10-A12).

Reduction of compounds (A4-A6) by ethanolic solution of hydrazine hydrate gave the corresponding ditellurides (A7-A9) in good yields. Furthermore, the diorganyl tellurides A13, A14 and A15 were prepared by the reduction of compounds A10, A11 and A12 respectively by hydrazine hydrate in boiling ethanol.

IR spectra for all compounds A6-A15 displayed common features in certain regions and characteristic bands in the fingerprint and other regions. The IR spectra of all prepared compounds show one or two broad strong bands in the rang $3498-3209 \mathrm{~cm}^{-1}$ due to $\mathrm{v}(\mathrm{O}-\mathrm{H})$. The IR spectra confirm the presence of the azomethine groups $(-\mathrm{CH}=\mathrm{N}-)$ stretching with a sharp region around $1633-1492 \mathrm{~cm}^{-1}$ (Table 1). The IR spectra of compounds (A6, A8, A11, A12, A14, A15) show a band at $1701-1622 \mathrm{~cm}^{-1}$ range can be attributed to carbonyl group $\mathrm{C}=\mathrm{O}$.

The ${ }^{1} \mathrm{H}$ NMR spectra of studied compounds A6- A10 and A13-A15 were recorded in DMSOd6 solution and show all the expected protons with proper intensity ratio, Table 1. It is worthy to note that the proton of azomethine resonate as a singlet between 9.70-7.88 ppm these values are in agreement with previously reported data [16.17]. The aromatic protons of all compounds appeared within the range $8.02-5.81 \mathrm{ppm}$ by singlet, doublet and multiple signals. The ${ }^{1} \mathrm{H}$ NMR spectra of compounds A6, A9 and $\mathbf{A} 15$ showed a singlet signal at 2.42, 2.42 and 2.38 ppm respectively due to methyl protons[18], compounds A7, A10 and A13 showed a singlet signal at 8.12, 7.65 and 5.86 ppm respectively can be attributed to amino protons [19], while compounds A8 and A14 showed singlet signal at $12.1 \mathrm{ppm}$ and $11.44 \mathrm{ppm}$ can be assign to hydroxyl proton for carboxyl group [18]. The signals of phenolic hydroxyl protons does not appear for all studied compounds [20,21].

The ${ }^{1} \mathrm{H}$ NMR spectra of compound $\mathbf{A} 9$ appeared two singlet signals at 7.94 and 7.88 ppm in ratio $3: 1$ as well as tow singlet signals at 2.42 and $2.38 \mathrm{ppm}$ in ratio $3: 1$, this confirms having of two rotational isomers: Trans rotamer $70 \%$ and Cis rotamer $30 \%$, this case appeared clearly in ${ }^{13} \mathrm{C}$ NMR spectrum .

Carbon-13 NMR spectra gave further support to the formation of these new compounds (Table 1). ${ }^{13} \mathrm{C}$ NMR spectra of compound $\mathbf{A} 6$ show a low field signal at $194.1 \mathrm{ppm}$ can be attributed to carbon atom of carbonyl group, while compound A9 it showed two signals at 192.93 and $192.54 \mathrm{ppm}$ due to carbonyl carbon atom for trans and cis isomers [22]. ${ }^{13} \mathrm{C}$ NMR spectra of $\mathbf{A 6}$ and $\mathbf{A} 9$ show a low field signal at $161.05 p p m$ and (162.66 ppm trans,161.52ppm cis) can be attributed to aromatic carbon atoms which attached with nitrogen atom $(\mathrm{CH}=\mathrm{N}-\mathrm{C})$ [23]. The spectra revealed the presence of $-\mathrm{CH}=\mathrm{N}$ group around $160 \mathrm{ppm}$. The ${ }^{13} \mathrm{C}$ NMR spectra show a high field at 25.67ppm for $\mathbf{A} 6$ and $(24.63 \mathrm{ppm}$ trans, $23.776 \mathrm{ppm}$ cis) for A9 due to carbon atom of methyl group [15].

The HSQC NMR spectrum of compound $\mathbf{A 6}$ shows the cross peak at $\delta \mathrm{H} / \delta \mathrm{C}=8.3 / 159 \mathrm{ppm}$ due to azomethine group $(\mathrm{N}=\mathrm{CH})$, a set of cross peaks: $\delta \mathrm{H} / \delta \mathrm{C}=7.9 / 116,7.3 / 128,7.1 / 130,7.5 / 116 \mathrm{ppm}$ and overlapping cross peak at $\delta \mathrm{H} / \delta \mathrm{C}$ $=7.6 / 131 \mathrm{ppm}$ can be assigned to aromatic protons and carbon . while the cross peak at $\delta \mathrm{H} / \delta \mathrm{C}=2.4 / 27 \mathrm{ppm} \mathrm{can} \mathrm{be}$ attributed to methyl group, Table 2, Figure 1.

The mass spectra of compounds A4, A7, A8 and $\mathbf{A} 15$ was recorded at $70 \mathrm{eV}$, and gave further support for its structures. The mass spectra of compound A4 exhibited the peak of molecular ion [M] ${ }^{+}$at $\mathrm{m} / \mathrm{z}(661)$ with a low intensity. While compounds A7, A8 and A15 do not exhibited the peaks owing to their molecular ions $[\mathrm{M}]^{+}[24,25]$. Nonetheless exhibited the fragments which due to these compounds. All compounds show peak at $m / z(201.9-202.0)$ with $43-100 \%$ abundance due to fragment ion $\left[\mathrm{C}_{6} \mathrm{H}_{5} \mathrm{Te}\right]^{+}[26]$ and peak at $\mathrm{m} / \mathrm{z}(81.7-82)$ with $28-100 \%$ abundance due to fragment ion $\left[\mathrm{C}_{4} \mathrm{O}_{2} \mathrm{H}_{2}\right]^{+}$. Important fragments were also observed, confirming the proposed structures.

\subsection{Invitro anti-tumor bioactivity of some studied compounds .}

Synthesized compounds have been tested for their anti tumor activity towards human PC3 and T24 cancer cells. Three compounds (A5, A6, and A18) show activity, Table 3. As a next step the activity of compound A18 was tested in a dose range between 3 and $100 \mu \mathrm{M}$ towards PC3 and T24 cells. Show the effect to cell growth inhibition (I\%) of PC3 and T24. The cell growth inhibition activity at $100 \mu \mathrm{M}$ is $96.02 \%$ towards PC3 and $94.84 \%$ towards T24. Table 3 shows that the half maximal inhibitory concentration (1C50), is a measure of the effectiveness of a compound in inhibiting biological. The range of IC50 is between 18.26 and $52.53 \mu \mathrm{M}$. While the range of IC50 is between 29.12 and $55.42 \mu \mathrm{M}$. 
In conclusion, a new series of symmetrical and unsymmetrical aryltellurium compounds were prepared by new and convenient method of these compounds exhibit some biological activity as antitumor compounds.

\section{Acknowledgements}

The authors are grateful to professor N. A. Al-Masoudi (Konstanz University, Germany) for providing some elemental analysis and NMR spectroscopy. Thanks are due to Sayed M. A. Shah, Northeast Normal University, China , for providing biological activity tests. We are also grateful to Department of chemistry, College of Education, Al-Basrah University, Iraq for providing the facilities.

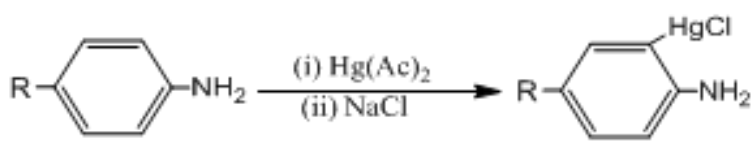

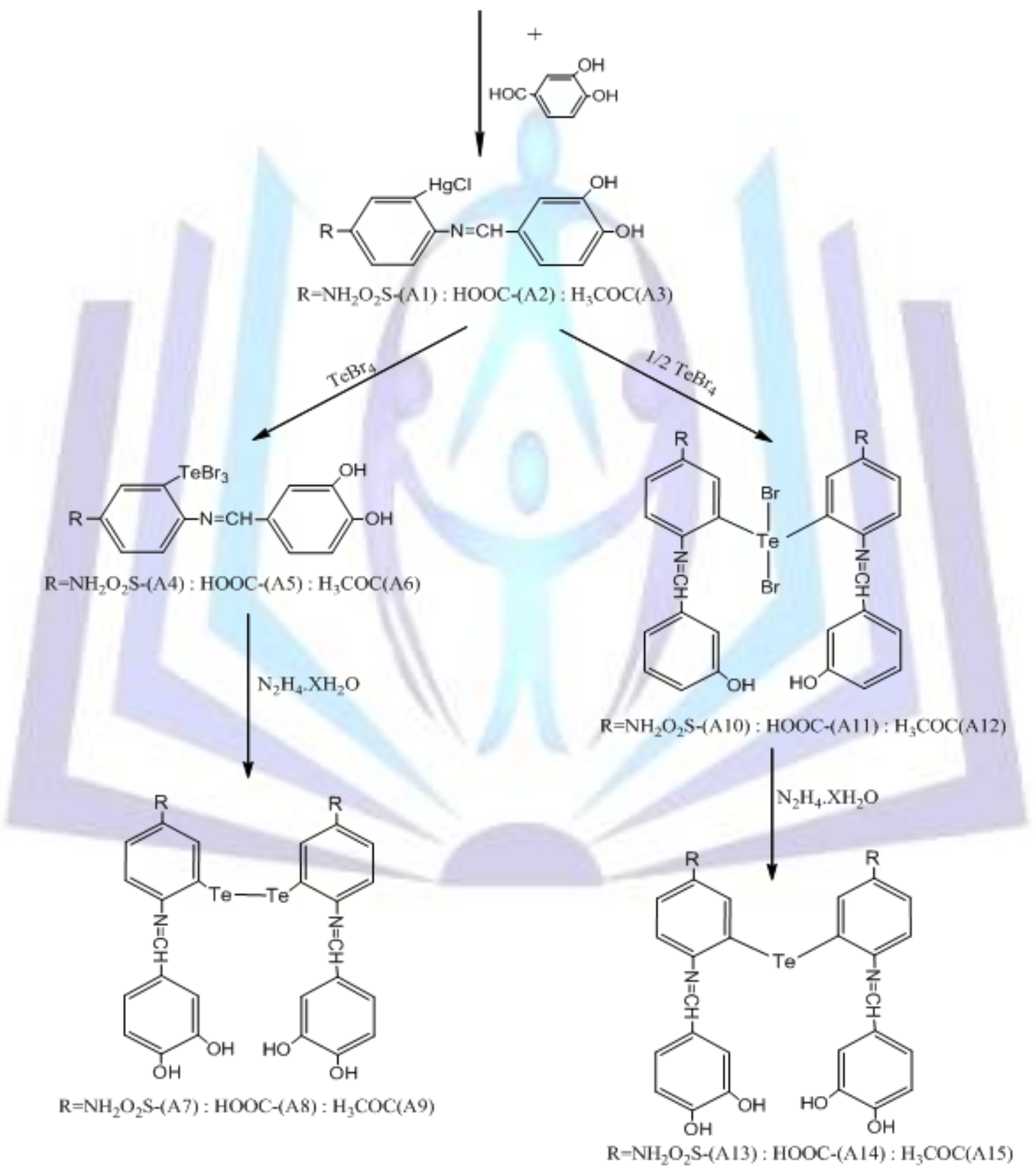

Scheme 1 : preparation methods of organotellurium compounds containing azomethaine group A1-A15 
Table 1 : Some physical properties, elemental analysis, Infra red and 1H NMR Spectroscopy for new organotellurium compounds containing azomethine group.

\begin{tabular}{|c|c|c|c|c|c|c|c|c|}
\hline Comp. & Color & $\begin{array}{l}\text { Melting } \\
\text { Point }\left({ }^{\circ} \mathrm{C}\right)\end{array}$ & Yield\% & \multicolumn{3}{|c|}{$\begin{array}{l}\text { Analysis;Calculated } \\
\text { (Found) }\end{array}$} & $\mathrm{IR} \mathrm{Cm}^{-1}$ & 'H NMR; DMSO-d6(ppm) \\
\hline$A 6^{a}$ & $\begin{array}{l}\text { Yellowish } \\
\text { brown }\end{array}$ & $\begin{array}{l}220-222 \\
\text { dec. }\end{array}$ & 85 & $\begin{array}{r}28.65 \\
(28.98)\end{array}$ & $\begin{array}{c}1.87 \\
(1.95)\end{array}$ & $\begin{array}{c}1.91 \\
(2.25)\end{array}$ & $\begin{array}{l}3435^{*}, 3024 \\
1685,1615\end{array}$ & $\begin{array}{l}2.42(\mathrm{~s}, 3 \mathrm{H}, \mathrm{CH} 3), 7.05- \\
7.89(\mathrm{~m}, 6 \mathrm{H}, \mathrm{Ar}-\mathrm{H}) 8.35(\mathrm{~s} \\
1 \mathrm{H}, \mathrm{CH}=\mathrm{N})\end{array}$ \\
\hline A7 & $\begin{array}{l}\text { Reddish } \\
\text { brown }\end{array}$ & $\begin{array}{l}208-210 \\
\text { dec. }\end{array}$ & 72 & $\begin{array}{r}36.93 \\
(37.27)\end{array}$ & $\begin{array}{c}2.55 \\
(2.64)\end{array}$ & $\begin{array}{c}6.60 \\
(6.68)\end{array}$ & $\begin{array}{l}3452,3055 \\
1618\end{array}$ & $\begin{array}{c}6.65(\mathrm{~d}, 2 \mathrm{H}, \mathrm{Ar}-\mathrm{H}), 7.70- \\
6.80(\mathrm{~m}, 8 \mathrm{H}, \mathrm{Ar}-\mathrm{H}), 8.02 \\
(\mathrm{~d}, 2 \mathrm{H}, \mathrm{Ar}-\mathrm{H}), 8.12(\mathrm{~s}, 4 \mathrm{H} \\
\left.\mathrm{NH}_{2}\right), 8.45(\mathrm{~s}, 2 \mathrm{H}, 2 \mathrm{CH}=\mathrm{N})\end{array}$ \\
\hline A8 & $\begin{array}{c}\text { Yellowish } \\
\text { brown }\end{array}$ & $\begin{array}{l}248-250 \\
\text { dec. }\end{array}$ & 77 & & & & $\begin{array}{l}3394,3209 \\
1680,1618\end{array}$ & $\begin{array}{l}\text { 6.81(d,2H, Ar-H),6.96(d, } \\
2 \mathrm{H}, \mathrm{Ar}-\mathrm{H}), 7.1(\mathrm{~s}, 2 \mathrm{H}, \mathrm{Ar}-\mathrm{H}), \\
7.88-7.64(\mathrm{~m}, 2 \mathrm{H}), 8.37(\mathrm{~s}, 2 \mathrm{H}, \\
2 \mathrm{CH}=\mathrm{N}), 12.10(\mathrm{~s}, 2 \mathrm{H}, 2 \mathrm{OH})\end{array}$ \\
\hline$A 9^{b}$ & $\begin{array}{l}\text { Dark } \\
\text { brown }\end{array}$ & $\begin{array}{c}180-182 \\
\text { dec. }\end{array}$ & 75 & $\begin{array}{r}47.07 \\
(47.18)\end{array}$ & $\begin{array}{l}2.98 \\
(3.17)\end{array}$ & $\begin{array}{c}3.44 \\
(3.66)\end{array}$ & $\begin{array}{l}3408,2910, \\
1622\end{array}$ & $\begin{array}{l}\text { Trans: } 2.42(\mathrm{~s}, 6 \mathrm{H}, \mathrm{CH} 3), \\
\text { 7.64-6.57 }(\mathrm{m}, 12 \mathrm{H}, \mathrm{Ar}-\mathrm{H}) \\
7.94(\mathrm{~s}, 2 \mathrm{H}, \mathrm{CH}=\mathrm{N}) . \\
\text { Cis: } 2.38(\mathrm{~s}, 6 \mathrm{H}, \mathrm{CH} 3), 7.64- \\
6.57(\mathrm{~m}, 12 \mathrm{H}, \mathrm{Ar}-\mathrm{H}), \\
7.88(\mathrm{~s}, 2 \mathrm{H}, \mathrm{CH}=\mathrm{N}) .\end{array}$ \\
\hline A10 & $\begin{array}{c}\text { Yellowish } \\
\text { brown }\end{array}$ & $\begin{array}{c}190-192 \\
\text { dec. }\end{array}$ & 70 & & & & $\begin{array}{l}3380,3350 \\
3229^{*}, 3109 \\
2900,1622\end{array}$ & $\begin{array}{l}\text { 6.55-7.53 (m,12H, Ar-H) } \\
\left.\text { 7.65(s, } 4 \mathrm{H}, \mathrm{NH}_{2}\right) \\
9.45 \mathrm{~s}, 1 \mathrm{H}, \mathrm{CH}=\mathrm{N})\end{array}$ \\
\hline A11 & Yellow & $\begin{array}{l}183-185 \\
\text { dec. }\end{array}$ & 69 & $\begin{array}{c}41.72 \\
(42.04)\end{array}$ & $\begin{array}{c}2.35 \\
(2.52)\end{array}$ & $\begin{array}{c}3.42 \\
(3.50)\end{array}$ & $\begin{array}{l}3466, \\
3371^{*}, \\
3105,1650 \\
1604\end{array}$ & \\
\hline A12 & Brown & $\begin{array}{l}172-175 \\
\text { dec. }\end{array}$ & 68 & & & & $\begin{array}{l}3435,3107 \\
2908,1624 \\
1595\end{array}$ & \\
\hline A13 & $\begin{array}{l}\text { Reddish } \\
\text { brown }\end{array}$ & $\begin{array}{c}175-177 \\
\text { dec. }\end{array}$ & 66 & $\begin{array}{c}43.51 \\
(43.97)\end{array}$ & $\begin{array}{l}3.07 \\
(3.12)\end{array}$ & $\begin{array}{l}7.31 \\
(7.88)\end{array}$ & $\begin{array}{l}3414,2902 \\
1624\end{array}$ & $\begin{array}{l}5.86\left(\mathrm{~s}, 4 \mathrm{H}, \mathrm{NH}_{2}\right), 6.59(\mathrm{~d}, 2 \mathrm{H}, \\
\mathrm{Ar}-\mathrm{H}), 6.96-6.86(\mathrm{~m}, 6 \mathrm{H}, \mathrm{Ar}-\mathrm{H}) \\
7.45(\mathrm{~d}, 2 \mathrm{H}, \mathrm{Ar}-\mathrm{H}), 7.77(\mathrm{~s}, 2 \mathrm{H}, \\
\mathrm{Ar}-\mathrm{H}), 8.11(\mathrm{~s}, 2 \mathrm{H}, 2 \mathrm{CH}=\mathrm{N})\end{array}$ \\
\hline A14 & Yellow & $\begin{array}{l}176-178 \\
\text { dec. }\end{array}$ & 77 & & & & $\begin{array}{l}3431,3060 \\
2960,1624 \\
2960\end{array}$ & $\begin{array}{l}6.81(\mathrm{~d}, 2 \mathrm{H}, \mathrm{Ar}-\mathrm{H}), 7.17(\mathrm{~d}, 2 \mathrm{H}, \\
\mathrm{Ar}-\mathrm{H}), 7.57-7.23(\mathrm{~m}, 6 \mathrm{H}, \mathrm{Ar}-\mathrm{H}) \\
7.65(\mathrm{~d}, 2 \mathrm{H}, \mathrm{Ar}-\mathrm{H}), 8.34(\mathrm{~s}, 2 \mathrm{H}, \\
2 \mathrm{CH}=\mathrm{N}), 11.33(\mathrm{~s}, 2 \mathrm{H}, \\
2 \mathrm{OH})\end{array}$ \\
\hline A15 & Brown & $\begin{array}{l}158-160 \\
\text { dec. }\end{array}$ & 71 & $\begin{array}{r}56.29 \\
(56.64)\end{array}$ & $\begin{array}{c}3.77 \\
(3.80)\end{array}$ & $\begin{array}{c}4.27 \\
(4.40)\end{array}$ & $\begin{array}{l}3439,3045 \\
2990,1622 \\
1577\end{array}$ & $\begin{array}{l}2.38\left(\mathrm{~s}, 3 \mathrm{H}, \mathrm{CH}_{3}\right), 6.58(\mathrm{~d}, \mathrm{Ar}-\mathrm{H}) \\
7.54-6.80(\mathrm{~m}, 8 \mathrm{H}, \mathrm{Ar}-\mathrm{H}), 7.68 \\
(\mathrm{~d}, 2 \mathrm{H}, \mathrm{Ar}-\mathrm{H}), 9.63(\mathrm{~s}, 2 \mathrm{H}, \mathrm{C}=\mathrm{N})\end{array}$ \\
\hline
\end{tabular}

${ }^{\text {a }{ }^{13} \text { C NMR in DMSO-d } 6: 194.10,161.05,159.46,146.25,141.75,130.10,128.03,125.16,116.52(2 C), 25.67 .}$ 
${ }^{b}{ }^{13}$ C NMR in DMSO-d : Trans rotamer, 192.93 , 162.66(2C), 160.11(2C), 146.24 (2C), 142.96 (2C), 132.37, 130.42, $126.07,117.37(4 \mathrm{C}), 24.63(2 \mathrm{C})$; Cis rotamer, $192.54(2 \mathrm{C}), 161.52(2 \mathrm{C}), 159.39(2 \mathrm{C})$,

$144.37(2 \mathrm{C}), 142.41(2 \mathrm{C}), 130.02,125.03,116.68(4 \mathrm{C}), 23.77(2 \mathrm{C})$.

Table 2: HSQC NMR data of compounds A6

\begin{tabular}{|c|c|c|c|}
\hline Compound structure & Position & Carbon (ppm) & Proton(ppm) \\
\hline 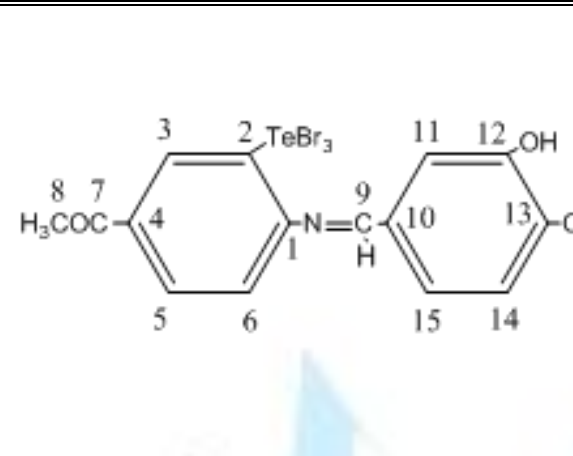 & $\begin{array}{c}3+6 \\
5 \\
8 \\
9 \\
11 \\
14 \\
15\end{array}$ & $\begin{array}{c}130 \\
128 \\
27 \\
159 \\
116 \\
116 \\
128\end{array}$ & $\begin{array}{l}7.5 \\
7.1 \\
2.4 \\
8.3 \\
7.5 \\
7.9 \\
7.3\end{array}$ \\
\hline
\end{tabular}

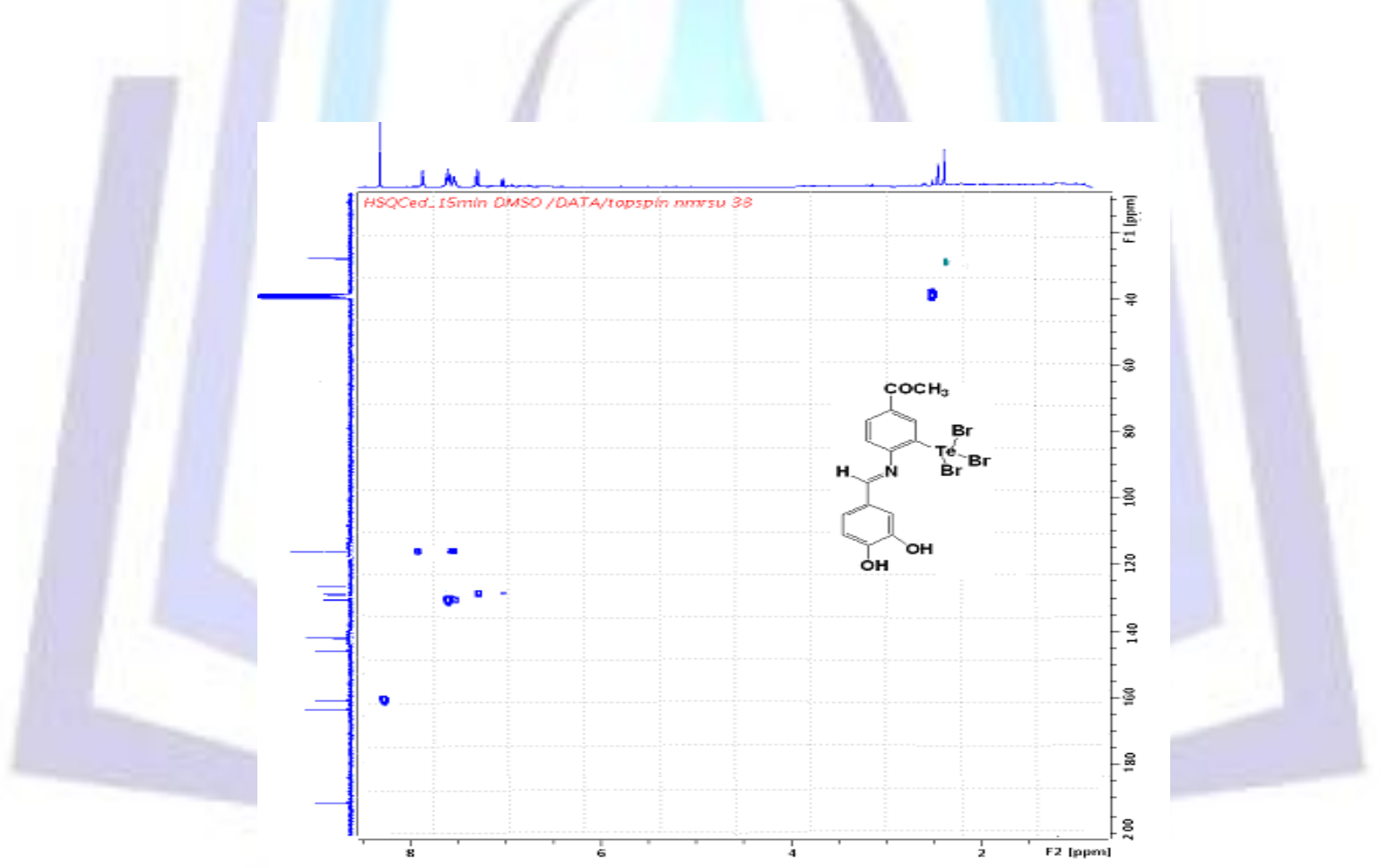

Figure 1: HSQC NMR spectrum of Compound A6 at $600 \mathrm{MHz}$ 
Table 3. Screening results of studied compounds against Prostate cancer cells PC24 and Bladder Cancer cells T24

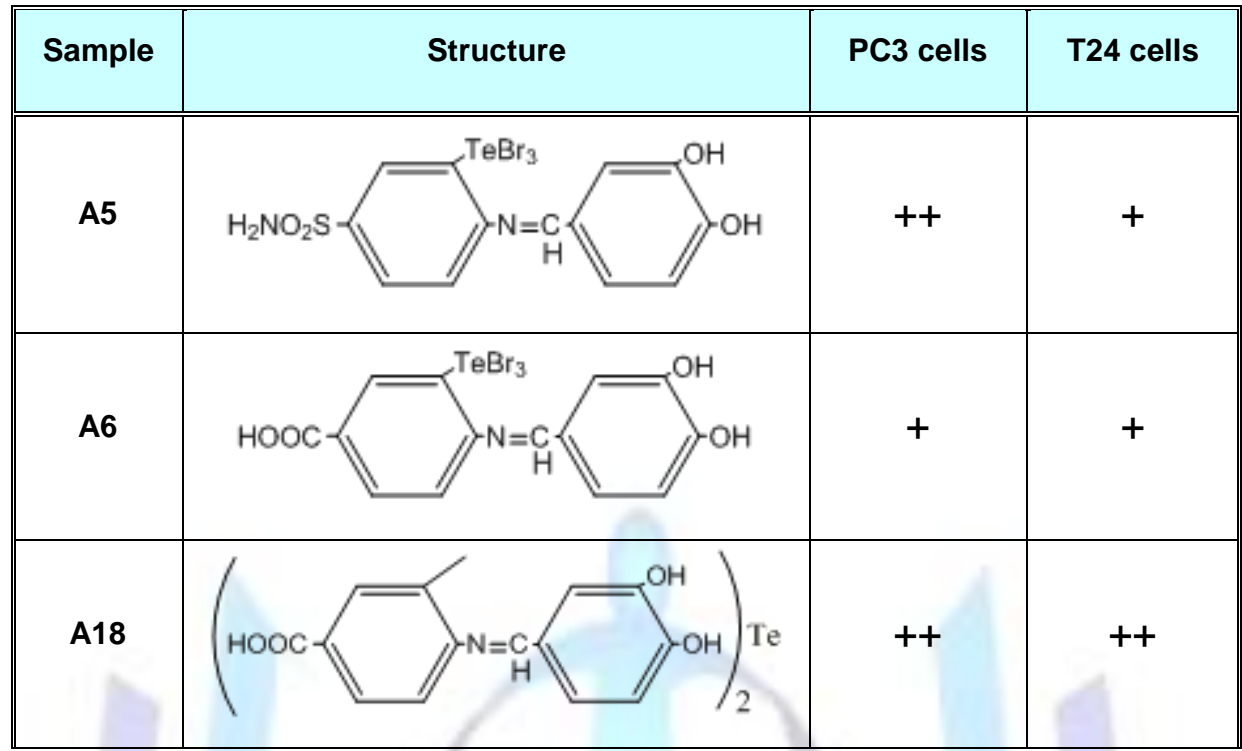

$+=$ low activity $\quad, \quad++=$ high activity

\section{REFERENCES}

[1] Cobbledick, R. E., Einstein, F. W. B., McWhinnie, W. R., and Musa, F. H., J. Chem. Soc. (S), 1979 , 145 ; (M) 19791901.

[2] Al-Rubaie, A. Z., Al-Salim, N. I., and Al-Jaddan, S. A. N., J.Organomet. Chem., 1993, 67, 443.

[3] Al-Rubaie, A. Z., Auoob, A. I., and Al-Allaf, T. A. K., Iraqi J. Chem. (1994).

[4] (a) Singh, H. B. and McWhinnie, W. R., J. Chem. Soc., Dalton Trans, 1985, 82. (b) Minkin, V. I., Maksimenko, A.

A., Mehrotra, G. K., Maslakov, A. G., Kompan, O. E., Sadekov, I. D., Struchkov,Y. U. T. and Yufit, D. S., J.Org.metChem., 1988, 63, 348

[5] Al-Rubaie, A. Z., Al-Masoudi, W.A., S.A.N.Al-Jadaan, S.A.N., Jalbout, A. F and Hameed, A.J,

J. Heteroatom Chem., 2008, 19, 3.

[6] Singh, H. B., Sudha, N., West, A. A., and Hamor, T. A., J. Chem. Soc., Dalton Trans, 1990, 907.

[7] Ahmed, M. A., McWhinnie, W. R., and Hamor, T. A., J.Organomet.Chem., 1985, 281, 205.

[8] Al-Rubaie, A. Z., Al-Salim, N. I., and Al-Jadaan, S. A. N., J.Organomet. Chem., 1993, 443, 67.

[9] Al-Rubaie, A. Z., and Al-Jadaan, S. A. N., Applied Org.metallic Chem., 1998, 12, 79.

[10] Khandellwal, B. L., Kumar, K., and Berry, F. J., Inorg. Chim. Acta., 1981, 47, 135.

[11] Petragnani, N., Comasseto, J. V., and Varella, N. H., J. Organomet.Chem., 1976, 120, 375.

[12] Sadekov, I. D., Maksimenko, A. A., Maslakov, A. G., and Minkin, V. I., J. Organomet. Chem.,1990, 391,179.

[13] Abed, Y., Al-Salim, N. I., Greaves, M. R., McWhinnie, W. R., West, A. A., and Hamor, T. A., J. Chem. Soc., Dalton Trans.,1989,1697.

[14] Sadekov, I. D., Maksimenko, A. A., Mehrota K. G., and Minkin, V. I., Zhur.Org. Khim., 1987, $23,1657$.

[15] Makarova and Nesmeyanov, The Organic Chemistry of Mercury Compounds' Methods of Elementry Organic Chemistry, 1976, 4, 94.

[16] Silerstien, R. M., Webster, F. X., and Kiemle, D. J., Spectrometric Identification of Organic Chemistry Compounds, $6^{\text {th }}$ Ed. , John Wiley and Sons , N. Y, 2005. 
[17] Asiri, A. M., and Khan, S.A., molecules, 2010, 15, 6850.

[18] Silverstein, R. M., Bassler, G. C., and Morrill, T. C., Spectrometric Identification of Organic Compounds", $5^{\text {th }}$ Ed., John Wiley, 1991.

[19] Mosula, L., Zimenkovsky, B., Havrylyuk, D., Missir, A., Chirita, I. C., and Lesyk, R., Farmacia, 2009, 3, 321.

[20] Abraham, R. G., and Mobli, M., Magn. Reson. Chem., 2007, 45, 865-877.

[21] Elias, R. S., Saeed, B. A., Saour, K. Y., and Al-Masoudi, N. A., Tetrahedron Lett., $2008,49,3049$.

[22] Al-Rubaie, A. Z., Al-Masoudi, W. A., Al-Jadaan, S. A., Jalbout, A. F., and Hameed, A. J., Hetroatom Chem., 2008, $19,307$.

[23] Martin, G. E., Cryogenic NMR Probs: Application, Grant, D. M., and Harris, R. K., Encyclopedia of Nuclear Magnetic Resonance, 2002, Vol.9, Wiley Chichester.

[24] Wu, Y., Ding, K., Wang,Y., Zhu, Y., and Yang, L., Organomet.Chem., 1994, 13, 46.

[25] Villegas, A., Garcia, P. G., Hopfl, H., Redondo, M., Salas, P. M., Cardoso, M. L., and Olivares, R. C.,

Organomet.Chem., 2011, 696, 2071.

[26] Albeck, M., and Shaik, S., J. Organomet.Chem., 1975, 91, 307. 